JARES, Vol. 3 No. 2 September, 2018; p-ISSN: 2502-826X; e-ISSN: 2503-1163

Copyrights@Balitar Islamic University, Blitar, Indonesia;

Http://jares.unisbablitar.ejournal.web.id

\title{
EFFECTIVE COMMUNICATION FOR SPECIAL NEEDS CHILDREN EDUCATORS
}

\author{
Ucik Ana Fardila \\ Institut Agama Islam Negeri Tulungagung \\ email: fardillaucikana@gmail.com
}

\begin{abstract}
Effective communication is very important for learning process in the class. Effective communication from teacher to parent especially has important role to reach learning achievement for children with special needs's classes. The key of well delivered communication is when communicator and communicant have the same message in a same perception thus will have a same understanding without meaning decreasion. Information could be delivered precisely and accurately if teacher and parent have a same understanding of the message. Communication system is necessary in children with special needs school system as the main tool of academic achievement evolvement, psychological achievement, and for student physical and mental development. Two way communication between teacher and parent become the main role of quality of children with special needs family. Communication from parent could help teacher have better knowledge about student that would help teacher to plan their class in the best method they could teach to be effective learning for each student. for children with special needs class could not only involve teacher and school system but also a good network system from parent and institutions from outside class that has impact in the children with special needs physical and mental development. It is necessary to have a certain system to connect every role in children with special needs environment to record their development through communication network system involving school, family, health institution and community as communication's instrument support so the learning achievement would be optimally performed.
\end{abstract}

Keywords: communication for special needs, communication in education, Special Needs 


\section{INTRODUCTION}

Communication has the main role in human life. A good two-way-communication quality will create a oneness of perception of both communicator and communicant resulted an effective communication. The communication is inside the system of organitational communication which is called as instruction communication in both verbal and non verbal communications. In the education system where children with special needs come to learn it is important to have a rapid communication system between school, educator, parent, concerned institution, government, and community where kids live. Written communication has became the most efficient and effective communication tools to connect home and school (Williams \& Cartledge, 1997: 30). Caspe (2003) suggested that teacher's plan and professional development school program should always be delivered through the quality of teacher's communication. Epstein (1995) explained that communication between teacher and parent is one of six main factor of parent involvement that build in communicative relationship between teacher and parent. The result of this relationship between this two important role in children with special needs education become the key of school development while school is an institution where people will be educated (Schussler, 2003).

Unfortunately let alone about communication system, the education system of children with special needs is under developed in Indonesia compared to other countries.

In 2010 the number of children with special needs in Indonesia reacher 1.6 million children but only 164 thousands children has well education service, in special school (SLB) or inclusive school. It means the number of kids education participation was only $10-11 \%{ }^{1}$ The institution faced some problems from several parts, first, many parents feel shy to send their special needs children in formal school, second, the lack of special needs facility from government from number of special school and inclusive school, especially in rural area, also, the lack of facility for children with special needs, in special and inclusive school, three, if parent has a willingness to submit their special needs child in the special school with a good facility, it will cost too much for average parents. Indonesian government has try to concern the education of children with special needs. At least it shown by the research that has been done by statistic Center Institute (Badan Pusat Statistik/ BPS) and other ministries and institutions, include Social Ministry, Education Ministry and Health Ministry. Sometimes they have different research result that potentially happened from differen conceptual, definition, research purpose and needs.

BPS as an official survey institution that claimed their concern about diffable children education claimed that they had done efforts to collect children with disability since 1980 in censuses and surveys that are:

- Netizen census in 1980 and 2010

- National Social Economy Survey (Survei Sosial Ekonomi Nasional/ Susenas) in 1998, 2000, 2002, 2003, 2006, 2009 and 2012

- Urban Potential Survey in 2002 (include disability in facility and home survey)

- Social Protection Data Collection (Pendataan Program Perlindungan Sosial/ PPLS) in 2008 and 2011

\footnotetext{
1 Presented by Dirjen Pendidikan Dasar dan Menengah (Dikdasmen) Hamid Muhammad in an article: "Kemendikbud Jamin Layanan Pendidikan Khusus". Edisi 04 November 2015. Retrieved from: http://www.kemdikbud.go.id/main/blog/2015/11/kemendikbud-jamin-layanan-pendidikan-khusus-4798-4798-4798.
} 
From Susenas's survey in 1998, 2000, 2003 and 2009 BPS was using handicapped defined disability community in definition handicapped as without or abnormaility from anatomy function and structure, psychological or physiological. Susenas's survey in 2006 was using disability and diffability. Disability was defined as unability to do some activities or work as how normal people do. While diffability was defined as the abnormality or impairment of body part and all caused imperfect or abnormal function of the body. Susenas's survey in 2012 was using disability definition that is defined unability to do any activity or work as how normal people do caused by any impairment (impairment/ unability) connected with age and community.

In May Mei 2014, BPS launched survey instrument and hand book for disability survey performance. The quesionaires were created by adopted questions recommended by Washington Group on Disabilities and the results were compared between regions and also compared between countries. The surveys had planned to be started in 2015 thus we expect data of disability community that could be used for any institution and ministry (every ministry had done their own survey before resulted different data considered as it might contradicted to each other). Since 2007 disability community data also collected by Basic Health Research (Riset Kesehatan Dasar/ Riskesdas) hold by Health Ministry and had been done in 2007, 2010, and 2013. The data of disability community had collected in Riskesdas research but only from age 15 years old and above (Buletin Jendela Data dan Informasi Kesehatan, Edisi Semester 2, 2014).

In other countries the diffable community concerns had been done many years before Indonesia. It was noted that from 2004 US government already had constitutions about diffable individual education (The Individuals with Disabilities Education Act/ IDEA of 2004) ensuring government concerns of special or specific education and services for 6.5 millions babies, children, teens of special needs (Education Ministry of US, 2009).

For US the network and relationship between school and home referenced as one of school achievement. At least the criteria was made by National Middle School Association from other 14 criterias to be an excellent school (Reilly, 2008). US community considered parents communication about school education had became an important role for education's policies. In 2000 President Bush said that American parents is the most important component for future academic achievement of American children (Shirvani, 2007).

Even if it is not yet in proportional number, Indonesia has tried to increase the number of education services for special needs children with inclusive school programs. Hildegun Olsen (Tarmansyah, 2007: 82) said that inclusive education is where school has accomodations to all children in any physical, intellectual, social emotional, linguistic conditions. The inclusive school must embrace not only disables but also special needs, stray kids and working kids from small community or no maden kids, kids from minority group or ethnic or culture, unfortunate kids and marginalized kids. Staub and Peck said that inclusive education is learning class for light, middle and serious disabilities in a whole class. It is shown that a regular class is the relevant place for any conditions kids to learn(Tarmansyah, 2007: 83). While Marthan claimed that inclusive education is an education service for children with special needs in regular school from elementary school, middle school, high school and vocation school; those special needs include abnormaility, slow learning, or other learning difficulties (Lay Kekeh Marthan, 2007:145). The performance of inclusive education needs a good effective and efficient communication between concerned education institutions and home. 
Communication patterns in education system is both two way communication pattern and one way communication pattern. One way communication include Newsletters: information sharing to parents and community; School Records usually used to give information for special needs parents, Home Visitation Records once or twice a week used to record development progress of special needs children to family, Academic Qualification that is traditional tool to show children achievement consists of evaluative informations. Two way communication include: dialogue parents and teacher. Dialogue should become communication to share information to each other but it used to be an ask and question about special needs children from parents to teacher. Parets asks and teacher answers. The most important thing from dialogue, it should be, two way communication based on beliveness that both have the same needs and same perspectives. (Lawrence-Lightfoot, 2004). Telephone is still considered as the best communication tool for teacher and parents. Another communication's tool is meeting confference for teacher and parents as it would become a good partnership initiation since teacher and parents placed in one level postition. Discussions in those conference could prevent blaming from each other side and try to solve the problem together. After the conference, communication between teacher and parents could not stopped there but must be followed up to brainstorm a certain strategic plan if it necessary or at least to analyse from each other peer.

Newest communication pattern is following technology and innovation development, include:

- Voice mail

- Video Technology

- School Website

- $\quad$ Electronic Mail

Communication is necessary in special needs education system as the key of academic performance, psychological and phisycal development achievement. Norman Kunc (1992) said that inclusive school system erased the idea that kids must be normal to be able to get education in formal school. In the inclusive education will allow children with any conidition to prepare them self for their future. Kunc also claimed that for adults, inclusive school program will teach adults how they should view community in the way every kids to be able to appreciate them self as one of community member thus every child has their own belonging of them self in the community (Kunc, 1992).

Communication between parents and school will help teacher to have better knowledge about special needs children that will help teacher to plan a better learning plan the way so that the students might follow the class more effectively.

\section{METHODOLOGY}

This research is a qualitative research with descriptive analysis method. The research has purpose to create an effective communication formula between special needs educators and family, concerned institutions of special needs education, government, and community. Research has been done by literature research to completed the formula based on literatures that shown the relationship between teacher, family, and other supports in Indonesia and other countries. The data analysed by critical analysis of researches and reports from national and international literatures. 


\section{RESULTS AND ANALYSIS}

Children with special needs defined as general kids and the same character with peers. Some aspects of children development, like character, communication ability (verbal and non verbal), endurance and power, to appreciate and enjoy life and learning willingness (NCSE, 2014). In an article, Terri Mauro said that special needs children is children with low learning willingness, or low cognitive, food allergic, acute illness, slow development that one time fast but another time retard, panic attack or serious psychiatric conditions (Mauro, 2016). KidsHealth.Org simplify the definition of special needs children as every children who need an extra help by the medical, emotional or learning reason. These kids are special needs because they must fllow medical supports regurlarly, therapies, or extra help from school that generally is not needed for another children or occasionally (Gavin, 2017).

Every school, especially teachers, need a teaching plan for special needs children so that children will achieve weel services, learning purpose, with understanding about child's conditions and parent's pressures (Very Well, 2016). Special needs parents might know their child conditions from pregnancy or when the chil was born. The reaction of the family could be accepted it well or denied the medical diagnosys from hospital, or even depressed from the results. In this condition it would need up to several years to accept their child's situation (Naseef, 2001: 207).

In the school, parents could have questions they want to ask to school. If parents needs help, school need to support parents to ask these questions:

1. Is my child working at or meeting the grade level outcomes? If not, why not? What would be the best way to proceed?

2. Is my child meeting the outcomes outlined in his or her individual education plan (IEP)? If not, why not? What would support my child's learning?

3. What do the scores or marks mean?

4. Is my child receiving adaptations or modifications to his or her work?

5. Does my child have major strengths or weaknesses in specific subject areas that I don't know about?

6. How would you describe my child's learning style?

7. What supports does my child need to learn? What strategies have worked well for my child?

8. Is it necessary for my child to go out of the classroom for resource help for periods of time? Why?

9. Has my child completed class assignments?

10. Has my child been attending classes regularly?

11. Are there any potential social issues with peers that I need to be aware of?

12. Does my child need a referral to the school resource teacher, speechlanguage, pathologist, psychologist, reading clinician, or guidance counsellor? What would be involved with the referral and how would that affect my child's programming?

13. What is the educational assistant's role with my child? How do I communicate with the educational assistant?

14. What can I/we do at home to support my/our child's learning? ${ }^{2}$

Major factors of an effective communication is when communicator and audiens receive message in same perception so that both will have the same understanding without

${ }^{2}$ A questions to ask list from Manitoba Education, Citizenship and Youth published in 2004, page 27. 
demeaning. Blue and Banning (2004: 175) said that school, teacers, and therapist involve family in their children educations by asking with simple quesionaires about simple informations to specific informations about their children's likes/ dislikes, their characters, competency, specific health or medical therapies, and contact for emergency. Researches proved that a good relationship between parents and children will help children's education development (Park, 2006). Knollmann and Wild (2007) found that students more enjoy doing their home work with parents than doing it alone, while another research found that for many students parents have an important role as motivator to finish their home work. Emotional's level of students when they were doing home work was not only influenced by parents precences but also the quality of those precences (Knollmann \& Wild, 2007). Another research showed that parents has a very major role in students academic level outcome (Comer, 2005).

Teacher and parents need to schedule a routine communications that could be informal conversations. This could decrease freeze conversations in parents-teacher's meeting if it was their first meeting and never communicated before.

In another side, one thing school and medics instititution have to remember is that family usually need time to accept their special needs children as Ulrich and Bauer (2003) claimed there are 4 phases, those are:

1. Olstrich phase. At this point parents don't deny their child's condition but don't realise all the effect for their child. The parents in this level would say, "He or she still like another children. He or she only like to be alone and read book."

2. Special Sign. Parents starts to realise their children are special needs and need a specific help or specific support from specific services.

3. Normalization. Parents try to not looking for difference between their children and other children without disability and decrease special classes and add more regular classes.

4. Self Actualization. Parents don't see the difference as something bad or good. Parents start to support their children to learn about their disability include how to be supporter for their own children.

Two way communication between teacher and parents is the key of special needs family development. School need to arrange parents meeting before first class or first school program. School with their programs and parents with theis children's conditions should share informations to each other as much as possible especially in the purpose of development and learning outcome and learning program design to achieve parents hopes. School especially teacher need to realise that work with special needs family will often meet with angry parents, emotional, confrontative, disbelief, or debate teacher's learning method. When it happen teacher need to resist to be also emotional. School and teacher should realise that parents must be their own guidance for the best education for their special needs children. And in other side some families faced experiences in other school or programs. Some other families might facing economy situation to give their special needs a proper therapy, or parents might don't agree with medical results from experts of school or school policy about their children conditions. School and teacher need to understand from parents point of view and try to prevent children from same experience in their old school thus would be a positive relationship and collaborative network between school and home (Ray et al, 2009). 
Teachers haev to use same colour, quality and size paper for bulletin as communication tools for parents. In the communication teachers need to use daily language (with readability $6^{\text {th }}$ grade or less; some computer software completed with age readibility); make sure to use words, spelling and information addition if it necessary (Aronson, 1995). Chambers (1998) claimed that school need to make a brochure that give a complete information for a new family who want to join to the new school environment.

In technology era like today, special needs educaors have the opportunity to communicate to special needs parents without time and space limits. Technology based communication could help communication faster from teachers to parents community (Ramirez, 2001). Nevertheless school need to use a simple communication's tool to let all parents could communicate to school and teachers radidly. However not all parents have a newes technology so school need to prepare the simplest communication's tools to be able to have a fast communications flow from school to home and opposite.

The barriers of communication between teachers and parents have several levels. In the level of social community, Brandt (1998) noted that researches tend to showed that community generally marginalized from government and school system. Taffel (2001) noted that many parents nowadays felt not supported, not understanded, and has too many requests (too busy of many responsibilities). The communication barriers should be able to be handled by school and teachers by showing that teachers appreciating even a little change to increase confidence and strong relationship, not only with parents but also with community in large. Local schools need to be an important part of community and schools have a benefit as the starter point through interactions with parents. Schools need to be a host or workshop facilities for parents in many topics about mental depression development and management. Schools could encourage support groups for parents to fulfill their needs in many more fields (Molland, 2004). Schools need to also prepare development mechanism of local governments to organize workshops, resources for families, foundations and participations through school's activitie and leadership program supports.

Judith Acosta claimed that at least seven steps need to be done by special needs educators to communicate with parents to prevent any communication barriers, those $\operatorname{are}^{3}$,:

1. Show to them school positition at the beginning - show it to parents that school has a function collaborator. Send cards, make a chat room and contact info. Show to them joy expression when working with their kids. Make sure that even if teachers are experts about education knowledge but parents are experts about their children knowledge thus teacher will accept and even need suggestions from parents.

2. Change the gear - take a deep breath and let it go from school activities. Working with parents is like working in team. Do self check-up about your habituals and tones. Was today exhausted? Is something bothered at home? Is that any correlations with your parents? Do you still able to be calm and kind? In this level, trusted friends from office would able to help doing self check-up more real.

3. Emotional problem solving - if you meet an angry parent and you respond it with anger too it surely will widen the problem. Even if teachers are attacked emotionally, teachers should not attack back. Assumed that you were not the cause of their emotions but schools, depression from taking care of children, pressure, and bad experiences in the past. If parents really got angry to teachers, give them eye contact, listen to them until

3 Sumber: http://www.eslteachersboard.com/cgi-bin/articles/index.pl?read=3661. Diunduh pada tanggal 4 Januari 2017. 
they finished their story, and try to understand what caused their anger and then resolve the problems.

4. Listen and empathy - keeping distance with problem will help teachers to listen more clam and empathy. When teachers do this, parents will be more calm and relax. Listening carefully is also a smart and easy way to understand the real problem and will not give a wrong directions caused by emotions.

5. Keep open mind - throw away assumptions. In facts many teachers don't know the real situations. Teachers got stories from part to part from many sources that could be secondary or third references. Prejudice, as guessing, in every problems, will prevent from productive relationships.

6. Best assumptions - at least until it proven the opposite. Of course if teachers need to react to every dangerous situations or serious bad problems, it would be better if law team of teachers or schools handle the problem. Before it happened give an assumption that parents only want the best for their children - eventhough parents themselves don't know what would best choice for their kids - and teachers always actively ask a way to connect, teach, and collaborate to parents.

7. Give time and schedule it for you - both professionally and privately matters. Give time for yourself to meet your parent conveniently, if it possible. And give time for yourself to take a rest with work partner, spouse, or even me-time for your self. If you think you are very depressed emotionally, take a rest as soon as possible. Do what you suggest to others.

In the way communication's network, Minister of Education, Citizenship and Youth Manitoba, Canada, give a handbook for school, parents, concerned institutions and community, pictured in a circle bellow:

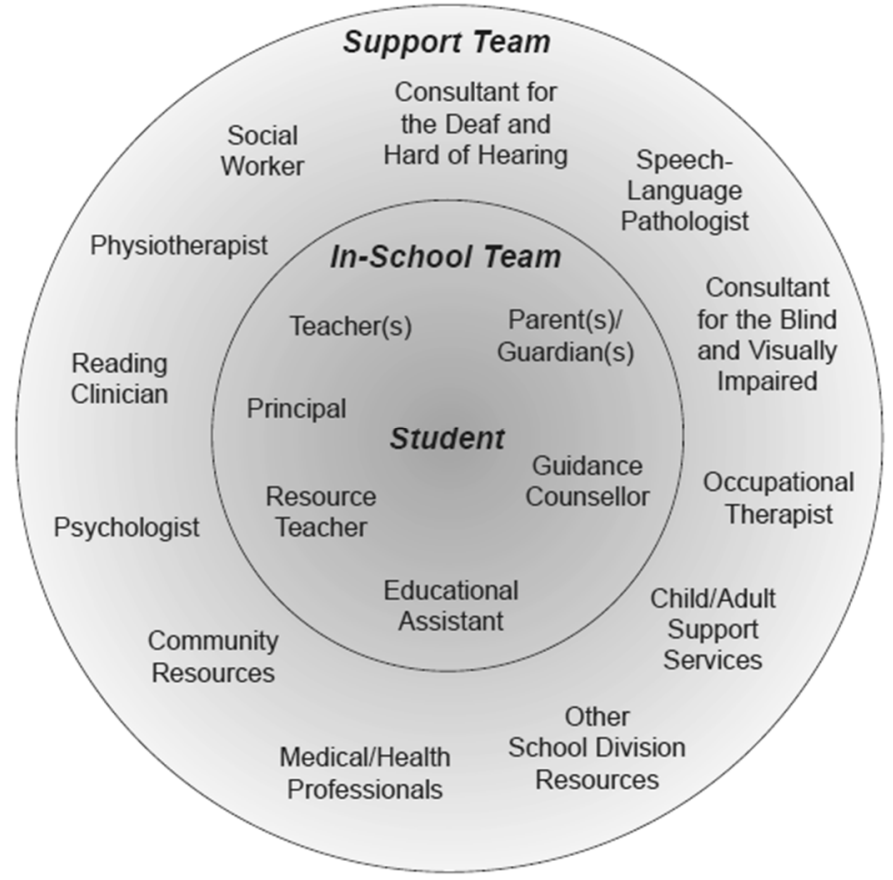

Figure 1. Network roles in special needs education communication system (Minister of Education, Citizenship and Youth. Manitoba Education, 2004). 
Network communication system for special needs in Manitoba consists of in-school team and support team. In-School team consists of Teacher(s), Parent(s), Principal, Resource Teacher, Guidance Counsellor, and Educational Assistant, with Student in the center of the network communication system. Support team consists of Consultant for the Deaf anad Hard of Hearing, Speech Language Parhologist, Consultant for the Blind and Visually Impaired, Occupational Therapist, Child/ Adult Support Services, Medical/ Health Proffesionals, Community Resources, Psychologist, Reading Clinician, Physiotherapist, Social, and Other School Division resources. In-School team are inside the circle while support team become the blanket. It means every team has their own role in special needs education system. Team inside the circle would create an intense communications by deleting any communication barrier possibilities of messages thus every messages would be sent effectively. Blanket team consists of important roles support to observe special needs children development. In-School team and support team need to communicate regularly and has a continuity record to minimalize any barrier communications between them.

A research done by Todd et al to autism parents in their school environments and foud that in the teacher plan preparation and administration processes, school need to have a class and workshop to help teacher increase their communication capability and strategy with and by involving parents in the process to implement education for students. These programs must able to create opportunities of teacher capacity development in understanding need and pressure of families with kids diagnosed with autism (Todd et al, 2014). In the Health Belief Model (HBM) theory it is said that health behavior is formed from beliefe or personal perception and strategy to decrease symptomps (Hochbaum, 1958). This theory emphasized that the failures of health programs used to occurred because concerned institutions did not give a proper informations thus public have their own perceptions and that was different from what was program offering for. Network communication between school-home-paramedics need to be build with start point from the idea that everyone need this. After every role have the same engagement of the idea, any programs from school, paramedics, and government could be practiced without barrier as long as there will always motivation to and from each other in the process.

The communication network suggested by Minister of Education, Citizenship and Youth is very suitable to be implemented for Indonesian formal school, both public and private schools. But it would be not enough if all role not connected neatly through a media. The complicated communication network system should have an information products as support instrument especially for special needs parents. Indonesia already has book record for Babies and Mothers, as instrument support to observe Indonesian children's health in the community. There are two record books, those are Mother and Kid Health Record (Buku Kesehatan Ibu dan Anak/ KIA) and Health Direction Card (Kartu Menuju Sehat /KMS) officially produced by Health Ministry of Indonesia. It records general development of mother and kid, like weight, height, immunizations and nutrition intake list. The scheme of communication network system instrument using Special Needs Health and Academic Record Book are shown bellow. As how KIA book and KMS card, the special needs book suggested to be produced by Health Ministry or another related government institution supported by school and concerned institution, group and community where special needs children live. In the book, every role, inside school team and support team, will record, students outcome, health record, include foundation, tools and facilities from government and community. In-School team will record student learning outcome in the class and support team will observe special needs children outside class, with medical, social and other explanations required for students development and achievement. School still give a learning 
outcome report for each semester as usual. But beside that report there will be another book that is Special Needs Health and Academic Record Book that record any development and outcomes or suggestions for parents or support team. With this method communication could be held in a very well system, information would delivered more effectively, not only from teacher to parents but also outside school could be able to observe special needs children development and outcomes more detail, sharp and comprehensive.

\section{Figure 2. Scheme of Communication Network System Instrument Using Special Needs Health and Academic Record Book (Buku Catatan Kesehatan dan Akademic ABK)*}

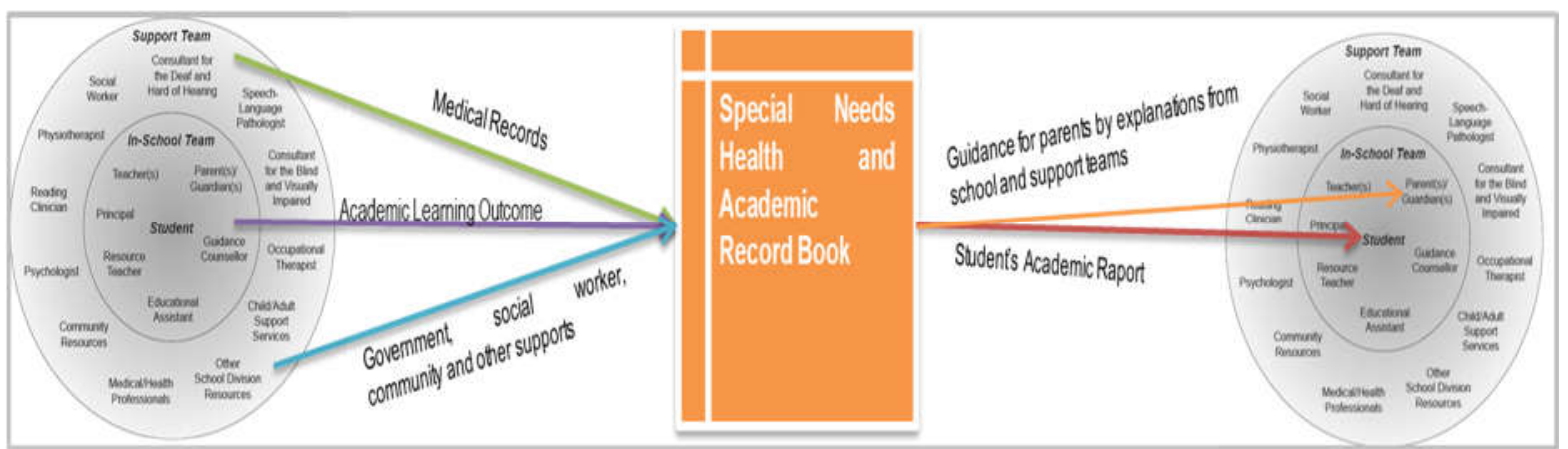

*modified from communication network suggested by Minister of Education, Citizenship and Youth of Minesota, Canada, 2004.

\section{CONCLUSIONS}

Communication is very important in learning process in the class. For special needs children, learning should be involve not only teacher and school environment but a whole environment where children live; not only academic but also medic and non medic support concerned to special needs development performances. Interpersonal communication pattern with any media alternatives, one way or two way communication pattern, would need a relationship management in an intense communications thus the development might observed in every seconds. Teachers or therapist as special needs educators in school must have a strong relationship building with parents and other supports.

Indonesia has a 9 years formal school obligation program policy that now it is becoming 12 years from elementary to high school grade. The policy had created to increase life quality of Indonesian children that could follow a better economy achievement with more prosperity in the future. It would need more reports to support this program especially in special needs children opportunity to be able to obligate the policy. The reports is one of communication media from government to show concern about education generally and special needs education, especially. The reports and other publications still limited today or the publication considered not pictured real situation in the country. While parents need to an issurance that their children will have same opportunity for education so that children, with any phisycal and mental health conditions, would be able to contribute in the community in their adult's life in the future. Government suggested to have a proper communication network system 
building with more detail to give every child their human right supported by certain policies to have a proper education and protection in the same level with another Indonesian children.

Special needs teacher or therapist in Indonesia has several types, those are special needs educators in Special School (SLB), special needs educator in private special needs school, and special needs teacher in inclusive school. If government has a willingness to actively involve in the development observation of special needs children student, the special needs education would more secured. The observation could be done with a media in a scheme of a network communication system using Special Needs Health and Academic Record Book (Buku Catatan Kesehatan dan Akademic ABK). This book would be the best support instrument for special needs children development and learning outcome performances, from academic, medic, psychologic, social, and law point of view. Thus the relationship betweeh home-school-community would be able to build more effectively, more detail, sharp and comprehensive.

\section{REFERENCES}

Acosta, Judith. The secrets of good parent-teacher communication -A brief handbook for teachers. Retrieved from http:/www.eslteachersboard.com/cgibin/articles/index.pl?read=3661. Diunduh pada tanggal 4 Januari 2017.

Aronson, M. M. (1995). Building communication partnerships with parents. Westminster, CA: Teacher Created Materials, Inc.

Blue-Banning, M., J.A. Summers, H.C. Frankland, L.L. Nelson, \& G. Beegle. 2004. Dimensions of family and professional partnerships: Constructive guidelines for collaboration. Exceptional Children 70(2): 167-84.

Brandt, R. (1998). Listen first. Educational Leadership, 55(8), 25-30.

Caspe, M. S. (2003). How teachers come to understand families. $\square$ e School Community Journal, 13(1), 115-131.

Chambers, L. (1998). How customer-friendly is your school? Educational Leadership, 56(2), 33-35.

Children Development Division, California Department of Education. 2009. Inclusion Works!: Creating Child Care Programs That Promote Belonging for Children with Special Needs. Diambil dari sumber: http://www.cde.ca.gov/re/pn. Diunduh pada tanggal 21 Desember 2016.

Comer, P. (2005). The rewards of parent participation. Educational Leadership, 62(6), 38-42.

Dolley, Amy. (20 Desember 2011). 5 Things Parents of Special Needs Students Want Teachers to Know Right Now. http://www.howtolearn.com/2011/12/5-things-parentsof-special-needs-students-want-teachers-to-know-right-now/print/. Diunduh pada tanggal 21 Desember 2016.

Epstein, J. (1995). School/family/community partnerships: Caring for the children we share. Phi Delta Kappan, 72(5), 701-712. 
Hochbaum, G. M., (1958). Public Participations in Medical Screening Programs: A SocioPsychologycal Study (Public Health Service Publication No.572). Washington DC. Government Printing Service.

Kementerian Kesehatan RI. 2014. Situasi Penyandang Disabilitas. Buletin Edisi Semester II 2014. Pusat Data dan Informasi Kementerian Kesehatan. Jakarta.

Knollmann, M. \& Wild, E. (2007). Quality of parental support and students' emotions during homework: Moderating effects of student motivational orientations. European Journal of Psychology of Education, 22(1), 63-76.

Kunc, N. "The Need to Belong: Restructuring Maslow's Hierarchy of Needs," in Restructuring for Caring and Effective Education: Administrative Guide to Creating Heterogeneous Schools. Edited by R. A. Villa; J. S. Thousand; W. Stainback; and S. Stainback. Baltimore, MD: Paul H Brookes, 1992, pp. 25-39.

Lawrence-Lightfoot, S. (2004). Building bridges from school to home. Instructor, 114(1), 2428.

Lay Kekeh Marthan. (2007). Manajemen Pendidikan Inklusif. Jakarta: DIRJEN DIKTI.

Manitoba Education, Citizenship and Youth Ministry. 2004. Working together : a handbook for parents of children with special needs in school. Diambil dari http://www.edu.gov.mb.ca/ks4/specedu/documents.html.

Molland, J. (2004). We're ALL WELCOME HERE. Instructor, 114(3), 22-25.

Naseef, R.A. 2001. The rudest awakening. In You will dream new dreams: Inspiring personal stories by parents of children with disabilities, eds. S.D. Klein \& K. Schive, 206-09. New York: Kensington Books.

National Council for Special Education. April, 2014. Children with Special Educational Needs: Information Booklet for Parents. Trim, County Meath, Irlandia.

Park, H. (2008). The varied educational effects of parent-child communication: A comparative study of fourteen countries. Comparative Education Review, 52(2), 219243.

Ramirez, F. (2001). Technology and parent involvement. Clearing House, 75(1), 30-31.

Ray, Julie A., Julia Pewitt-Kinder, Suzanne George. 2009. Partnering with Families of Children. Young Children. Edisi September 2009. Dapat diunduh di www.naeyc.org/yc.

Reilly, E. (2008) Parental involvement through better communication. Middle School Journal, 39(3), 40-47.

Schussler, D. L. (2003). Schools as learning communities: Unpacking the concept. Journal of School Leadership, 13, 498-528. 
Shirvani, H. (2007). Effects of teacher communication on parents' attitudes and their children's behaviors at schools. Education, 128(1), 34-47.

Taffel, R. (2001). Getting through to difficult kids and parents. New York: Guilford Press. Tarmansyah. (2007). Inklusi Pendidikan Untuk Semua. Jakarta: Depdiknas.

Todd, Teri A., Jennifer Beamer, Joan Goodreau. (2014). Bridging the Gap: Teacher-Parent Partnerships for Students With Autism Spectrum Disorder. Learning Landscapes. 8 (1). 278-304.

U.S. Department of Education. 2009. Building the legacy of IDEA 2004. http://idea.ed.gov.

Ulrich, M.E., \& A.M. Bauer. 2003. Levels of awareness: A closer look at communication between parents and professionals. Teaching Exceptional Children 35 (6): 20-24.

Williams, V. I., \& Cartledge, G. (1997). Passing notes-to parents. Teaching Exceptional Children, 30(1), 30-34. 